\title{
Fabrication of Organic Solar Cells based on Photosensitive Small Molecules and Study of Electron Acceptor Layer Effect on Efficiency
}

\author{
Priyanka P. Kumavat, Dipak S. Dalal* \\ School of Chemical Sciences, North Maharashtra University, Jalgaon - 425 001(M.S.), India \\ Email: dsdalal2007@gmail.com
}

\begin{abstract}
We have designed and synthesized an efficient and novel photosensitive two small organic molecules with different lengths of methine units, cyano groups as the electron acceptor units, and amino groups as the electron donor units. Compound 1 was synthesized from benzaldehyde, malononitrile and hydrazine hydrate and benzaldehyde whereas compound 2 was synthesized from benzaldehyde, Dimedone and hydrazine hydrate and their thermal, phovoltaic and surface properties were studied. Then these small molecules were utilized for development of organic solar cells in FTO: ZnO: Organic compound: Electrolyte: Pt electrode pattern.
\end{abstract}

Keywords: Organic solar cells (OSCs), zinc oxide ( $\mathrm{ZnO})$, titanium Oxide $\left(\mathrm{TiO}_{2}\right)$, electrolyte, efficiency.

\section{Introduction}

Organic solar cells (OSCs) have attracted significant interest because of their great potential to become green energy source with large-area, light-weight, superior mechanical flexibility, and low cost processes by roll-to-roll manufacturing [1-4]. Zinc oxide $(\mathrm{ZnO})$ is a versatile semiconductor material, with wide range of applications in photo electrochemical cells [5], lasers [6], and other electrical devices [7, 8]. ZnO is a promising candidate for contact layers in next-generation thin-film photovoltaics because it is a lowcost, non-toxic, earth-abundant material with multiple solution deposition routes to the formation of thin films [9]. $\mathrm{ZnO}$ is a wide band gap semiconductor with an energy gap of $3.3 \mathrm{eV}$ and a conduction band edge of $4.3 \mathrm{eV}$. This band edge is sufficiently high to extract electrons from typical donor and acceptor molecules and/or polymers [10]. There are many methods used for the $\mathrm{ZnO}$ deposition like spin coating, atomic layer deposition, screen printing, nano-imprinting, pulsed laser deposition, spin-cast and spray coating etc [10-14].

Diego Barrera et al reported thermal annealing of $\mathrm{P}_{3} \mathrm{HT}$ :PCBM bulk heterojunctions (BHJs) on top of a commonly used sol-gel $\mathrm{ZnO}$ electron transport layer leading to the formation of PCBM clusters [15]. Fabrication of a bilayer hybrid organic solar cell with $\mathrm{P} 3 \mathrm{HT}$ as the donor and $\mathrm{ZnO}$ as the acceptor $(\mathrm{ITO} / \mathrm{ZnO} / \mathrm{P} 3 \mathrm{HT} / \mathrm{Au}$ ) having the power conversion efficiency of the self-assembled monolayer modified device was approximately $60 \%$ higher than that of the untreated device [16]. Synergistic effect of dual interfacial modifications with room-temperature-grown epitaxial $\mathrm{ZnO}$ and adsorbed indoline dye for $\mathrm{ZnO}$ nanorod array/P3HT hybrid solar cell giving efficiency of $1.16 \%$ has been reported [17]. The P3HT:PCBM-based flexible organic solar cells (FOSCs) fabricated by brush-painting processes have been reported to have a power conversion efficiency of $2.055 \%$ [18]. The synthesis of poly(3hexylthiophene) (P3HT)/HA ZnO nanocomposite by in situ polymerization has been reported with the solar to electric energy conversion efficiency of $0.1238 \%$ [19].

In continuation of our research work in synthesis [20-25] and solar cell [26], herein we report the synthesis of 5-amino-3-phenyl-2, 3-dihydro-1H-pyrazole-4-carbonitrile (1) and 6, 6-dimethyl-3-phenyl2,3,6,7-tetrahydro- $1 \mathrm{H}$-indazol-4(5H)-one (2) organic compounds. Their optical, thermal and photovoltaic properties are investigated. A power efficiency efficiencies upto $0.077 \%$ has been obtained under simulated solar irradiation. 


\section{$2 \quad$ Experimental}

\subsection{Chemicals and Instrumentations}

Dimedone was purchased from sd-fine chem limited, India. Benzaldehyde and malononitrile were purchased from Spectrochem chemicals. Ethylene glycol was purchased from Fischer scientific and hydrazine hydrate was purchased from Sigma Aldrich.

${ }^{1} \mathrm{H}-\mathrm{NMR}$ and ${ }^{13} \mathrm{C}-\mathrm{NMR}$ spectra were recorded on a Bruker Advance II spectrometer operating at 300 and $75 \mathrm{MHz}$, respectively. Liquid Chromatography-High resolution mass (LC-HR-MS) spectra were recorded on a 6550 iFunnel QTOF LC-MS/MS Make-Agilent Technologies 1290 Infinity Binary Pump. The thermogravimetric analyses (TGA) were carried out on a Perkin Elmer 4000 Instrument under purified nitrogen gas flow with a $10^{\circ} \mathrm{C} \mathrm{min}^{-1}$ heating rate. Surface roughness and morphology of thin films were characterized by Field Emission-Scanning Electron Microscopy (FE-SEM) on an S-4800 instrument from Hitachi, Japan, operated at $10 \mathrm{kV}$ (Kilo Volt) and elemental analysis was performed by the EDS unit coupled with the FE-SEM unit. Film thicknesses were measured by using a thickness profiler DEKTAK- 150 profilometer for area $1000 \mathrm{~nm}$. The current density-voltage (J-V) characteristics of the organic solar cells (OSCs) were measured under AM1.5G (100mWcm2) illumination which was provided by a 3A grade solar simulator (Newport, USA, 94043A, calibrated with a standard crystalline silicon solar cell).

\subsection{Synthesis}

5-amino-3-phenyl-2, 3-dihydro-1H-pyrazole-4-carbonitrile (1)

A mixture of benzaldehyde (5mmol), malononitrile $(5 \mathrm{mmol})$, hydrazine hydrate $(99 \%)(5 \mathrm{mmol})$ and $20 \mathrm{~mol} \% \mathrm{Al}_{2} \mathrm{O}_{3}$ in $5 \mathrm{ml}$ ethylene glycol was refluxed at $100-120^{\circ} \mathrm{C}$ for $3 \mathrm{hrs}$. After cooling to room temperature, the reaction mixture was poured in ice cold water, a yellow solid precipitated out which was then filtered. The obtained crude product was then purified by silica gel column chromatography using ethyl acetate and hexane to give an orange solid product.

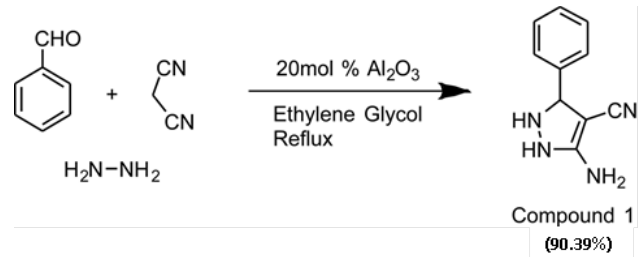

Yield: $90.39 \%$

${ }^{1} \mathrm{H}$ NMR (300MHz, DMSO): 4.297-4.35 (s, 2H), 5.554-5.67 (s, 1H), 6.755-6.80 (d, 2H), 7.440-7.64 (m, $3 \mathrm{H}), 8.297-8.50(\mathrm{~s}, 2 \mathrm{H})$

${ }^{13} \mathrm{C}$ NMR (75MHz, DMSO): 70.7, 73.9, 83.2, 97.5, 127.6, 127.9, 128.4, 129.3, 129.8, 133.6, 133.9, 160.3

GC-HR-MS: Calculated for $\mathrm{C}_{10} \mathrm{H}_{10} \mathrm{~N}_{4}$ 186.0887; found for $\left(\left[\mathrm{C}_{10} \mathrm{H}_{10} \mathrm{~N}_{4}\right]+\mathrm{H}\right) 187.096$

6, 6-dimethyl-3-phenyl-2,3,6,7-tetrahydro-1H-indazol-4(5H)-one (2)

A mixture of benzaldehyde $(5 \mathrm{mmol})$, dimedone $(5 \mathrm{mmol})$, hydrazine hydrate $(99 \%)(5 \mathrm{mmol})$ and $20 \mathrm{~mol} \% \mathrm{NiCl}_{2}$ in $5 \mathrm{ml}$ ethylene glycol was refluxed at $100-120^{\circ} \mathrm{C}$ for $5 \mathrm{hrs}$. After cooling to room temperature, the reaction mixture was poured in ice cold water, a yellow solid precipitated out which was then filtered. The obtained crude product was then purified by silica gel column chromatography using ethyl acetate and hexane to give a yellow solid product.

Yield: $80.34 \%$

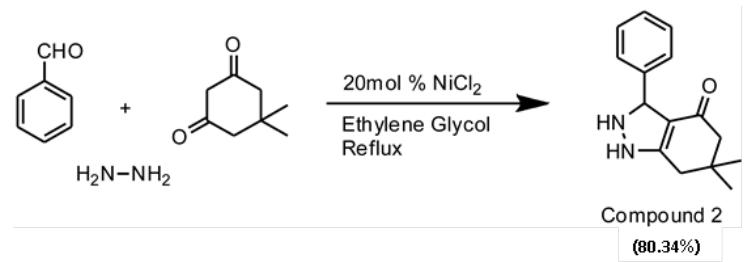


${ }^{1} \mathrm{H}$ NMR (300MHz, DMSO): 0.93-1.91 (s, 6H), 2.07-2.49 (s, 2H), 2.50-2.77 (s, 2H), $4.65(\mathrm{~m}, 3 \mathrm{H}), 7.30-$ 7.594 (m, 3H), 7.73-7.79 (d, 2H)

${ }^{13} \mathrm{C}$ NMR $(75 \mathrm{MHz}$, DMSO): 20.7, 27.5, 30.9, 62.4, 126.8, 127.9, 128.5, 129.6, 134.1, 161.1, 171.7

GC-HR-MS: calculated for $\mathrm{C}_{15} \mathrm{H}_{18} \mathrm{~N}_{2} \mathrm{O} 242.1409$; found for $\left(\left[\mathrm{C}_{15} \mathrm{H}_{18} \mathrm{~N}_{2} \mathrm{O}\right]+\mathrm{H}\right) 243.1476$

\subsection{Fabrication of Solar Cell Devices}

Solar cells were fabricated on pre-patterned Fluorine doped Tin Oxide (FTO) ultrasonically cleaned with acetone, toluene, methanol, and isopropyl alcohol subsequently. Onto the FTO glass, acceptor layer of $\mathrm{ZnO}$ film was coated by SILAR (Successive Ionic Layer Adsorption and Reaction) technique shown in Figure 1. For SILAR technique, initially $50 \mathrm{~mL}$ of $0.1 \mathrm{M} \mathrm{Zn}\left(\mathrm{NO}_{3}\right)_{2}$ was prepared by dissolving appropriate amount of zinc nitrate in $50 \mathrm{~mL}$ distilled water. Similarly, $0.2 \mathrm{M}$ of $\mathrm{NaOH}$ solution was prepared. The pre-clean FTO glass was dipped into the solution of $0.1 \mathrm{M} \mathrm{Zn}\left(\mathrm{NO}_{3}\right)_{2}$ for 10 second then rinsed with distilled water and finally immersed in $0.2 \mathrm{M}$ of $\mathrm{NaOH}$ solution at $60^{\circ} \mathrm{C}$ for 10 second. Then again it was rinsed with distilled water for the completion of one cycle. Similarly, 150 cycles were performed for deposition of $\mathrm{ZnO}$ layer and then annealed at $350^{\circ} \mathrm{C}$ for $1 \mathrm{~h}$ in air. In some devices, acceptor layer $\mathrm{TiO}_{2}$ was used which was coated on FTO by dip coating method [26]. Then solutions of the organic compound 1 and compound 2 of concentrations $10 \mathrm{mM}$ in ethanol were prepared and coated on FTO/ZnO by simple dipping method at $60^{\circ} \mathrm{C}$ for 10 minutes. Then electrolyte was introduced into OSCs. Two electrolytes were used containing $0.05 \mathrm{M}$ of $\mathrm{I}_{2}$ solution in Ethyl carbonate: Acetonitrile (80:20) and $0.5 \mathrm{M}$ of tetra-n-butyl ammonium iodide, $0.05 \mathrm{M} \mathrm{I}_{2}$ in propylene carbonate: acetonitrile (6:4 volumes) and covered with platinum plate as counter electrode. Schematic representation of fabricated devices was shown in Figure 2.

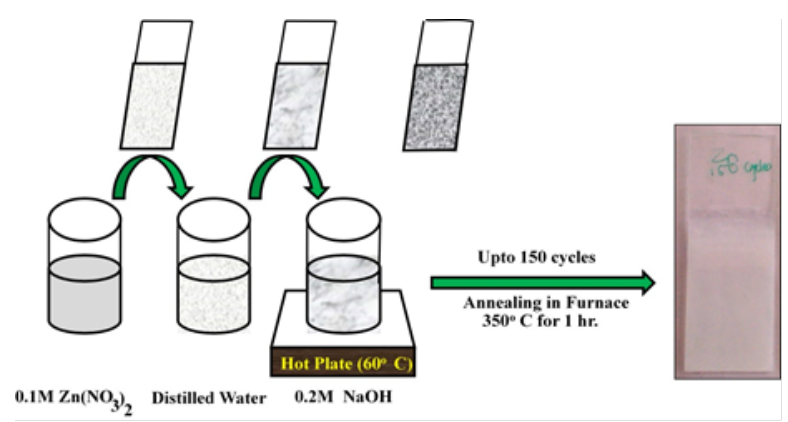

Figure 1. Coating of $\mathrm{ZnO}$ by SILAR technique

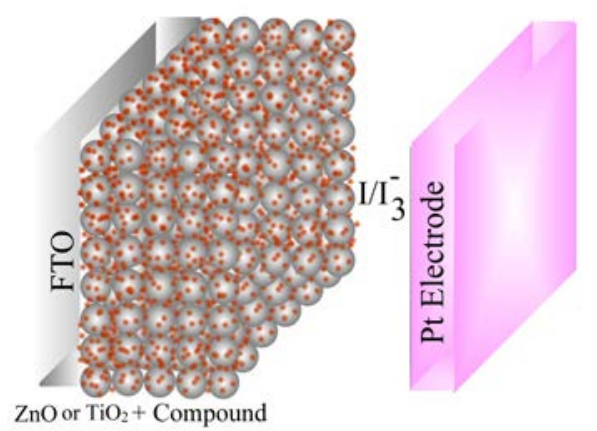


Figure 2. Schematic representation of fabricated devices

\section{$3 \quad$ Result and Discussion}

\subsection{Thermal Stability of Organic Compounds}

The thermal property of both compounds is investigated by thermogravimetric analysis (TGA). Compounds 1 and 2 exhibit good thermal stability with a decomposition temperature (5\% weight loss) of $106^{\circ} \mathrm{C}$ and $242^{\circ} \mathrm{C}$ respectively in nitrogen shown in Figure 3 .

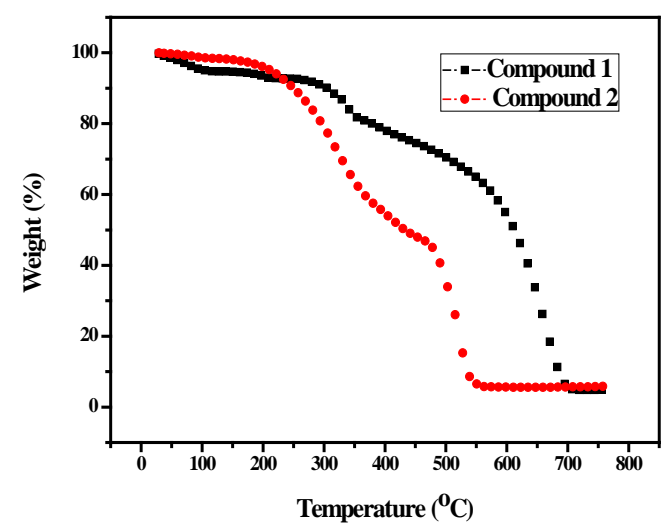

Figure 3. TGA of Compound 1 and Compound 2

\subsection{Surface Characterization}

FE-SEM is utilized to study the morphology of $\mathrm{ZnO}$ and $\mathrm{ZnO} /$ organic compound films. For this purpose, active layers were coated on glass plates using fabrication process described in section 2.3 and the morphology and EDX are shown in Figure 4. Figure (4a) shows nano-sized ZnO particles. Figure (4b) and (4c) show coating of organic compounds 1 and 2 on $\mathrm{ZnO}$, respectively with increase in particle size, which confirm the successful coating of organic compounds over ZnO nanoparticles. EDX analysis (Figure 4) shows elemental composition of respective films and EDX spectra confirm the presence of respective elements in films.
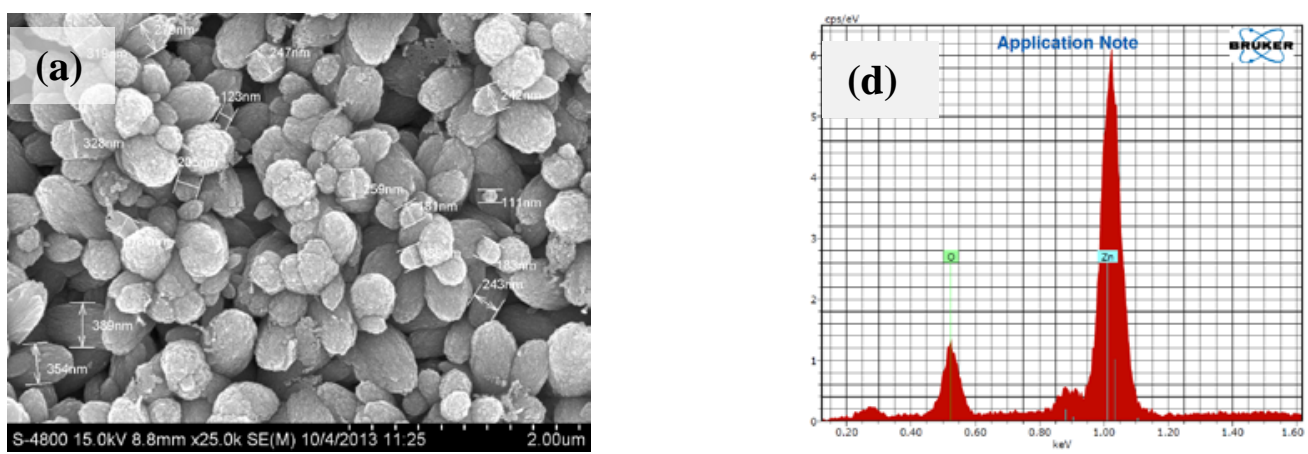

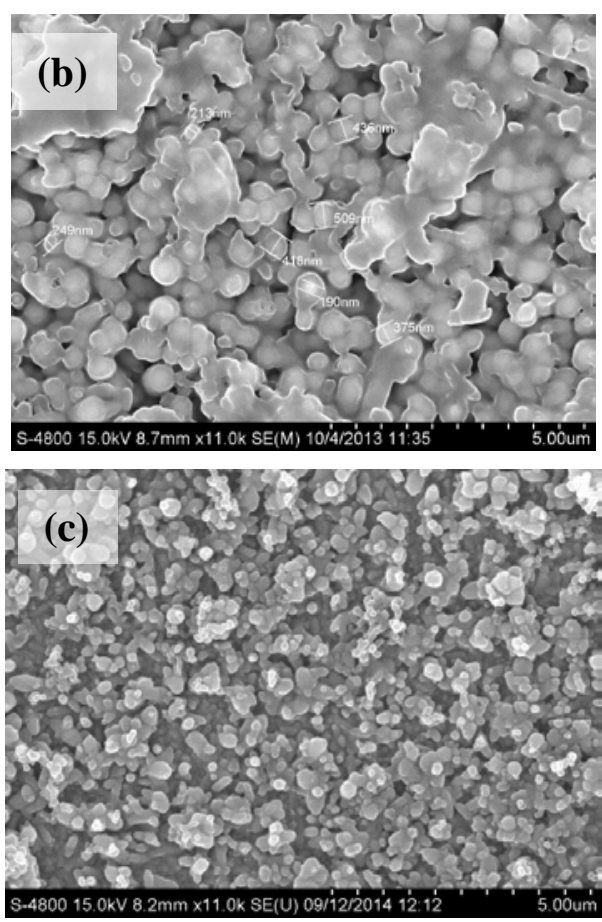
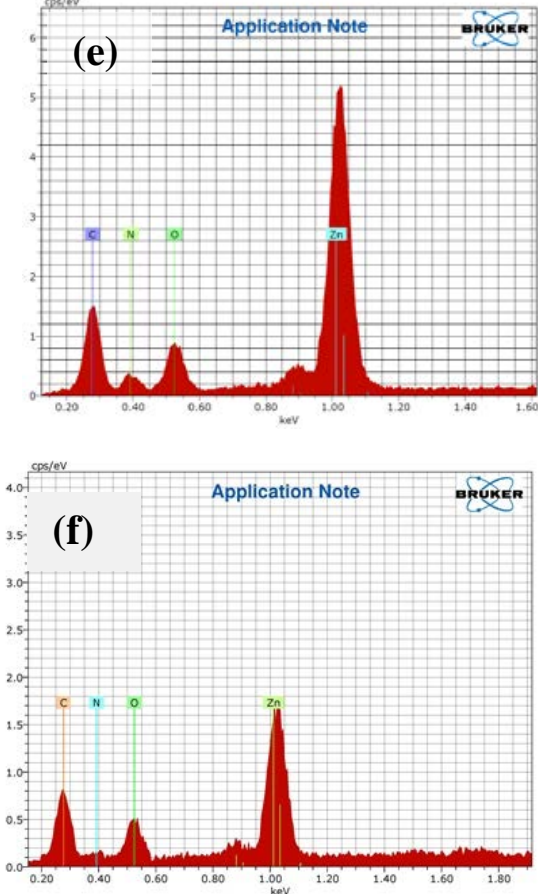

Figure 4. FE-SEM images of (a) ZnO film (b) Compound 1 coated on $\mathrm{ZnO}$ film (c) Compound 2 coated on $\mathrm{ZnO}$ film and EDS images of (d) $\mathrm{ZnO}$ film (e) Compound 1 coated on $\mathrm{ZnO}$ film (f) Compound 2 coated on $\mathrm{ZnO}$ film

\subsection{Photovoltaic Properties}

OSCs prepared with different device structures altering donor, acceptor and electrolyte composition and their photovoltaic characteristics are shown in Table 1. Different combinations of OSCs as FTO/acceptor/organic compound/electrolyte/Pt were prepared and tested under a simulated AM 1.5G illumination $\left(100 \mathrm{~mW} / \mathrm{cm}^{2}\right)$. Different compositions of acceptor and organic compounds were used to optimize the device performance and their current density vs. voltage $(\mathrm{J}-\mathrm{V})$ curves are shown in Figure 5 . Out of these different compositions, device P-1 has shown maximum efficiency of $0.077 \%$ with 0.576 $\mathrm{V}$ as Voc and $0.418 \mathrm{~mA} / \mathrm{cm}^{2}$ as Jsc. From the results it can be concluded that small and simple organic compounds can be used in fabrication of OSCs.

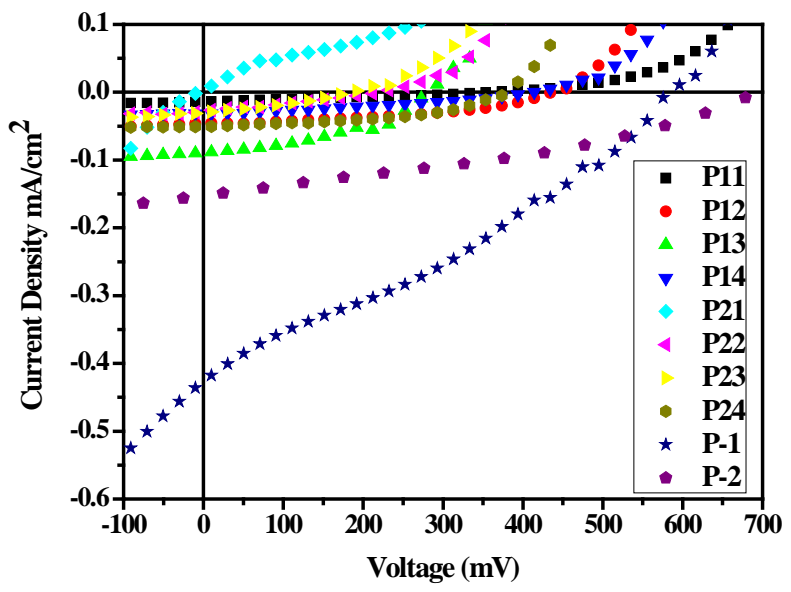

Figure 5. The $\mathrm{J}-\mathrm{V}$ characteristics of the different devices under the AM 1.5 illumination at $100 \mathrm{~mW} / \mathrm{cm}^{2}$ condition 
Table 1. Characteristics of different OSCs device performance

\begin{tabular}{|c|c|c|c|c|c|c|c|}
\hline $\begin{array}{l}\text { Device } \\
\text { No. }\end{array}$ & $\begin{array}{l}\text { Device } \\
\text { Code }\end{array}$ & Device Material & Electrolyte & $\begin{array}{l}\text { Voc } \\
(\mathrm{V})\end{array}$ & $\begin{array}{l}\mathrm{Jsc} \\
\left(\mathrm{mA} / \mathrm{cm}^{2}\right)\end{array}$ & FF & $\begin{array}{l}\text { \% } \\
\text { Efficiency } \\
(\eta)\end{array}$ \\
\hline 1 & $\mathrm{P}-1$ & $\begin{array}{l}\text { FTO: } \mathrm{ZnO} \text { (SILAR): } \\
\text { Organic compound (P-1): } \\
\text { Electrolyte: Pt electrode }\end{array}$ & $\begin{array}{l}0.05 \mathrm{M} \mathrm{I}_{2} \text { solution in } \\
(80: 20) \text { Ethyl carbonate: } \\
\text { Acetonitrile }\end{array}$ & 0.575 & 0.418 & 0.320 & 0.077 \\
\hline 2 & P-2 & $\begin{array}{l}\text { FTO: } \mathrm{ZnO} \text { (SILAR): } \\
\text { Organic compound (P-2): } \\
\text { Electrolyte: Pt electrode }\end{array}$ & $\begin{array}{l}0.05 \mathrm{M} \mathrm{I}_{2} \text { solution in } \\
(80: 20) \text { Ethyl carbonate: } \\
\text { Acetonitrile }\end{array}$ & 0.693 & 0.152 & 0.367 & 0.039 \\
\hline 3 & P-11 & $\begin{array}{l}\text { FTO: } \mathrm{ZnO} \text { (SILAR): } \\
\text { Organic compound (P-1): } \\
\text { Electrolyte: Pt electrode }\end{array}$ & $\begin{array}{l}0.5 \mathrm{M} \text { of tetra-n-butyl } \\
\text { ammonium iodide, } 0.05 \\
\mathrm{M} \mathrm{I}_{2} \text { in propylene } \\
\text { carbonate/acetonitrile } \\
\text { (6:4 volumes) }\end{array}$ & 0.353 & 0.014 & 0.302 & 0.001 \\
\hline 4 & $\mathrm{P}-12$ & $\begin{array}{l}\text { FTO: } \mathrm{ZnO} \text { (SILAR): } \\
\mathrm{ZnO(Dip} \mathrm{coating):} \\
\text { Organic compound (P-1): } \\
\text { Electrolyte: Pt electrode }\end{array}$ & $\begin{array}{l}0.5 \mathrm{M} \text { of tetra-n-butyl } \\
\text { ammonium iodide, } 0.05 \\
\mathrm{M} \mathrm{I}_{2} \text { in propylene } \\
\text { carbonate/acetonitrile } \\
\text { (6:4 volumes) }\end{array}$ & 0.434 & 0.046 & 0.455 & 0.009 \\
\hline 5 & $\mathrm{P}-13$ & $\begin{array}{l}\text { FTO: } \mathrm{TiO}_{2} \text { : Organic } \\
\text { compound }(\mathrm{P}-1) \text { : } \\
\text { Electrolyte: } \text { Pt electrode }\end{array}$ & $\begin{array}{l}0.5 \mathrm{M} \text { of tetra-n-butyl } \\
\text { ammonium iodide, } 0.05 \\
\mathrm{M} \mathrm{I}_{2} \text { in propylene } \\
\text { carbonate/acetonitrile } \\
\text { (6:4 volumes) }\end{array}$ & 0.299 & 0.088 & 0.454 & 0.012 \\
\hline 6 & P-14 & $\begin{array}{l}\text { FTO: } \mathrm{ZnO} \text { (SILAR): } \\
\text { TiO2: Organic compound } \\
\text { (P-1): Electrolyte: } \mathrm{Pt} \\
\text { electrode }\end{array}$ & $\begin{array}{l}0.5 \mathrm{M} \text { of tetra-n-butyl } \\
\text { ammonium iodide, } 0.05 \\
\mathrm{M} \mathrm{I}_{2} \text { in propylene } \\
\text { carbonate/acetonitrile } \\
\text { (6:4 volumes) }\end{array}$ & 0.414 & 0.032 & 0.341 & 0.005 \\
\hline 7 & $\mathrm{P}-21$ & $\begin{array}{l}\text { FTO: } \mathrm{ZnO} \text { (SILAR): } \\
\text { Organic compound (P-2): } \\
\text { Electrolyte: Pt electrode }\end{array}$ & $\begin{array}{l}0.5 \mathrm{M} \text { of tetra-n-butyl } \\
\text { ammonium iodide, } 0.05 \\
\mathrm{M} \mathrm{I}_{2} \text { in propylene } \\
\text { carbonate/acetonitrile } \\
\text { (6:4 volumes) }\end{array}$ & - & - & - & - \\
\hline 8 & $\mathrm{P}-22$ & $\begin{array}{l}\text { FTO: } \mathrm{ZnO} \text { (SILAR): } \\
\mathrm{ZnO(Dip} \mathrm{coating):} \\
\text { Organic compound (P-2): } \\
\text { Electrolyte: Pt electrode }\end{array}$ & $\begin{array}{l}0.5 \mathrm{M} \text { of tetra-n-butyl } \\
\text { ammonium iodide, } 0.05 \\
\mathrm{M} \mathrm{I}_{2} \text { in propylene } \\
\text { carbonate/acetonitrile } \\
\text { (6:4 volumes) }\end{array}$ & 0.232 & 0.026 & 0.292 & 0.002 \\
\hline 9 & P-23 & $\begin{array}{l}\text { FTO: } \mathrm{TiO}_{2} \text { : Organic } \\
\text { compound (P-2): } \\
\text { Electrolyte: Pt electrode }\end{array}$ & $\begin{array}{l}0.5 \mathrm{M} \text { of tetra-n-butyl } \\
\text { ammonium iodide, } 0.05 \\
\mathrm{M} \mathrm{I}_{2} \text { in propylene } \\
\text { carbonate/acetonitrile } \\
\text { (6:4 volumes) }\end{array}$ & 0.192 & 0.029 & 0.330 & 0.002 \\
\hline 10 & P-24 & $\begin{array}{l}\text { FTO: } \mathrm{ZnO} \text { (SILAR): } \\
\mathrm{TiO}_{2}: \text { Organic compound } \\
(\mathrm{P}-2): \text { Electrolyte: } \mathrm{Pt} \\
\text { electrode }\end{array}$ & $\begin{array}{l}0.5 \mathrm{M} \text { of tetra-n-butyl } \\
\text { ammonium iodide, } 0.05 \\
\mathrm{M} \mathrm{I}_{2} \text { in propylene } \\
\text { carbonate/acetonitrile } \\
\text { (6:4 volumes) }\end{array}$ & 0.394 & 0.051 & 0.457 & 0.009 \\
\hline
\end{tabular}




\section{Conclusion}

We reported the synthesis and characterization of novel 5-amino-3-phenyl-2,3-dihydro-1H-pyrazole-4carbonitrile and 6,6-dimethyl-3-phenyl-2,3,6,7-tetrahydro- $1 \mathrm{H}$-indazol-4(5H)-one compounds which have different lengths of methine units, cyano groups as the electron acceptor units, and amino groups as the electron donor units. These synthesized novel organic compounds were utilised for fabrication of organic solar cells in FTO: ZnO: Organic compound: Electrolyte: Pt electrode pattern producing up to $0.077 \%$ solar energy-to-electricity conversion efficiency $(\eta)$.

Acknowledgements: One of the authors (PPK) acknowledges UGC, New Delhi, for SAP (DSA-I) fellowship under the scheme 'Research Fellowship in Sciences for Meritorious Students'.

\section{References}

1. Y.H. Zhou, C.F. Hernandez, J. Shim, J. Meyer, A.J. Giordano, H. Li, P. Winget, T. Papadopoulos, H. Cheun, J. Kim, “A Universal Method to Produce Low-Work Function Electrodes for Organic Electronics" Science, vol. 336, pp. 327-332, 2012.

2. M. Jorgensen, K. Norrman, S.A. Gevorgyan, T. Tromholt, B. Andreasen, F.C. Krebs, "Stability of polymer solar cells" Advanced Materials, vol. 24, pp. 580-612, 2012.

3. S.Y. Park, Y.J. Kang, S. Lee, D.G. Kim, J.K. Kim, J.H. Kim, J.W. Kang, "Spray-coated organic solar cells with large-area of $12.25 \mathrm{~cm}^{2} "$ Solar Energy Materials and Solar Cells, vol. 95, pp. 852-855, 2011.

4. H. Jin, C.Tao, M. Velusamy, M. Aljada, Y.L. Zhang, M. Hambsch, P.L. Burn, P. Meredith, "Efficient, Large Area ITO-and-PEDOT-free Organic Solar Cell Sub-modules" Advanced Materials, vol. 24, pp. 2572-2577, 2012.

5. L. Bahadur, M. Hamdani, J.F. Koenig, P. Chartier, "Studies on semiconducting thin films prepared by the spray pyrolysis technique for photoelectrochemical solar cell applications: Preparation and properties of ZnO" Solar Energy Materials, vol. 14, pp. 107-120, 1986.

6. L. Znaidi, G.S Illia, S. Benyahia, C. Sanchez, A.V. Kanaev, "Oriented ZnO thin films synthesis by sol-gel process for laser application" Thin Solid Films, vol. 428, pp. 257-262, 2003.

7. X.L. Cheng, H. Zhao, L.H. Huo, S. Gao, J.G. Zhao, "ZnO nanoparticulate thin Im: Preparation, Characterization and gas sensing property" Sensors and Actuators B: Chemical, vol. 102, pp. 248-252, 2004.

8. H. Li, J. Wang, H. Liu, H. Zhang, X. Li, "Zinc oxide films prepared by sol-gel method" Journal of Crystal Growth, vol. 275, pp. 943-946, 2005.

9. S.R. Cowan, P. Schulz, A.J. Giordano, A. Garcia, B.A. MacLeod, S.R. Marder, A. Kahn, D.S. Ginley , E.L. Ratcliff , D.C. Olson, "Chemically Controlled Reversible and Irreversible Extraction Barriers Via Stable Interface Modification of Zinc Oxide Electron Collection Layer in Polycarbazole-based Organic Solar Cells" Advanced Functional Materials, vol. 24, pp. 4671, 2014.

10. M.J. Jin, J. Jo, J.H. Kim, K.S. An, M.S. Jeong, J. Kim, J.W. Yoo, "Effects of $\mathrm{TiO}_{2}$ interfacial atomic layers on device performances and exciton dynamics in $\mathrm{ZnO}$ nanorod polymer solar cells" ACS Applied Materials 8 Interfaces, vol. 6, pp. 11649-11656, 2014.

11. N. Chaturvedi, S.K. Swami, A. Kumar, V. Dutta, "Role of ZnO nanostructured layer spray deposited under an electric field in stability of inverted organic solar cells" Solar Energy Materials 83 Solar Cells, vol. 126, pp. 74-82, 2014.

12. D. Duche, F. Bencheikha, S.B. Dkhil, M. Gaceur, N. Berton, O. Margeat, J. Ackermann, J.J. Simon, "Optical performance and color investigations of hybrid solar cells based on P3HT:ZnO, PCPDTBT:ZnO, PTB7:ZnO and DTS(PTTh2) 2 :ZnO” Solar Energy Materials \& Solar Cells, vol. 126, pp. 197-204, 2014.

13. J. J. Intemann, K. Yao, Y.X. Li , H.L. Yip, Y.X. Xu , P.W. Liang ,C.C. Chueh, F.Z. Ding, X. Yang, X. Li , Y. Chen, A.K.Y. Jen, "Highly Efficient Inverted Organic Solar Cells Through Material and Interfacial Engineering of Indacenodithieno[3,2-b]thiophene-Based Polymers and Devices" Advanced Functional Materials, vol. 24, pp. 1465-1473, 2014 
14. S.H. Eom, M.J. Baek, H. Park, L. Yan, S. Liu, W. You, S.H. Lee, "Roles of Interfacial Modifiers in Hybrid Solar Cells: Inorganic/Polymer Bilayer vs Inorganic/Polymer:Fullerene Bulk Heterojunction" ACS Applied Materials E Interfaces, vol. 6, pp. 803-810, 2014.

15. D. Barrera, Y.J. Lee, J.W.P. Hsu, "Influence of $\mathrm{ZnO}$ sol-gel electron transport layer processing on BHJ active layer morphology and OPV performance" Solar Energy Materials \&3 Solar Cells, vol. 125, pp. 27-32, 2014.

16. J.M. Chiu, Y. Tai, "Improving the Efficiency of ZnO-Based Organic Solar Cell by Self-Assembled Monolayer Assisted Modulation on the Properties of ZnO Acceptor Layer" ACS Applied Materials \& Interfaces, vol. 5, pp. 6946-6950, 2013.

17. D.W. Chen, T.C. Wang, W.P. Liao, J.J. Wu, "Synergistic effect of dual interfacial modifications with roomtemperature-grown epitaxial $\mathrm{ZnO}$ and adsorbed indoline dye for $\mathrm{ZnO}$ nanorod array $/ \mathrm{P}_{3} \mathrm{HT}$ hybrid solar cell" ACS Applied Materials \& Interfaces, vol. 5, pp. 8359-8365, 2013.

18. S.B. Kang, Y.J. Noh, S.I. Na, H.K. Kim, "Brush-painted flexible organic solar cells using highly transparent and flexible Ag nanowire network electrodes" Solar Energy Materials \& Solar Cells, vol. 122, pp.152-157, 2014.

19. P. Sehgal, A.K. Narula, "Poly(3-hexylthiophene)/hexamine modified ZnO hybrid nanocomposite: structural, optical, thermal and electrical transport studies" Journal of Materials Science: Materials in Electronics, vol. 25, pp. 4793-4799, 2014.

20. P.P. Kumavat, A.D. Jangale, D.R. Patil, K.S. Dalal, J.S. Meshram, D.S. Dalal, Green synthesis of symmetrical $\mathrm{N}, \mathrm{N}^{-}$-disubstituted thiourea derivatives in water using solar energy" Environmental Chemistry Letters, vol. 11, pp. 177-182, 2013.

21. D.R. Patil, Y.B.Wagh, P.G. Ingole, K. Singh, D.S. Dalal, “ $\beta$-Cyclodextrin-mediated highly efficient $[2+3]$ cycloaddition reactions for the synthesis of 5-substituted 1H-tetrazoles, New Journal of Chemistry, vol. 37, pp. 3261-3266, 2013.

22. Y.A. Tayade, D.R. Patil, Y.B. Wagh, A.D. Jangale, D.S. Dalal, "An efficient synthesis of 3-indolyl-3-hydroxy oxindoles and 3,3-di(indolyl)indolin-2-ones cat alyzed by sulfonat ed $\beta-\mathrm{CD}$ as a supramolecular catalyst in water" Tetrahedron Letters, vol. 56, pp. 666-673, 2015.

23. Y.A. Tayade, S.A. Padvi, Y.B. Wagh, D.S. Dalal, " $\beta$-Cyclodextrin as a supramolecular catalyst for the synthesis of dihydropyrano[2,3-c]pyrazole and spiro[indoline-3,4 - -pyrano[2,3-c]pyrazole] in aqueous medium" Tetrahedron Letters, vol. 56, pp. 2441-2447, 2015.

24. Y.B. Wagh, A. Kuwar, S.K. Sahoo, J. Gallucci, D.S. Dalal, "Highly selective fluorimetric sensor for $\mathrm{Cu}^{2+}$ and $\mathrm{Hg}^{2+}$ using a benzothiazole-based receptor in semi-aqueous media and molecular docking studies" RSC Advances, vol. 5, pp. 45528-45534, 2015.

25. A.D. Jangale, P.P. Kumavat, Y.B. Wagh, Y.A. Tayade, P.P. Mahulikar, D.S. Dalal, "Green Process Development for the Synthesis of Aliphatic Symmetrical N,N ${ }^{-}$-Disubstituted Thiourea Derivatives in Aqueous Medium" Synthetic Communications, vol. 45, pp. 376-385, 2015.

26. P.P. Kumavat, P.K. Baviskar, B.R. Sankapal, D.S. Dalal, "Synthesis of D-D-A-type small organic molecules with an enlarged linker system towards organic solar cells and the effect of co-adsorbents on cell performance" New Journal of Chemistry, vol. 40, pp. 634-640, 2016. 